\title{
Development of an Appropriate Rice-Based Biomass Gasifier as Source of Power for Farm Use
}

\author{
Alexis T. Belonio, Manuel Jose C. Regalado, Phoebe R. Castillo \\ Philippine Rice Research Institute, Central Experiment Station, Science City of Munoz, Philippines \\ Email: atbelonio@yahoo.com, manueljoseregalado@yahoo.com,phoebe_castillo87@yahoo.com
}

How to cite this paper: Belonio, A.T., Regalado, M.J.C. and Castillo, P.R. (2018) Development of an Appropriate Rice-Based Biomass Gasifier as Source of Power for Farm Use. Open Access Library Journal, 5: e5054.

https://doi.org/10.4236/oalib.1105054

Received: November 16, 2018

Accepted: December 18, 2018

Published: December 21, 2018

Copyright $\odot 2018$ by authors and Open Access Library Inc.

This work is licensed under the Creative Commons Attribution International License (CC BY 4.0).

http://creativecommons.org/licenses/by/4.0/

\begin{abstract}
An appropriate rice-based (ARB) biomass gasifier was designed and developed for farmers' use. The gasification properties of rice-based biomass were determined before doing the design. The gasifier was built using salvage petrol drums, metal bars and concrete as primary construction materials. It has a $30 \mathrm{~cm}$-diameter reactor insulated with refractory cement. A $10 \mathrm{~cm}-\phi$ cross flow scrubber with $30 \mathrm{~cm}$-thick packed-bed filter is used for conditioning the gas. The gas is converted to mechanical power with the use of a four-stroke-cycle, spark ignition engine commonly used by farmers. The gasifier was tested and underwent series of modifications and improvements. Performance test and evaluation showed that the gasifier performs satisfactorily as per design. Raw rice husk was found to have greater advantage as fuel for the gasifier than rice straw. It can drive stationary agricultural machines such as a 4 -in. pump, a $30-\mathrm{cm}$ biomass chipper, and a $20-\mathrm{cm}$ rubber creeping mill. It can also power a 3-kWe AC generator for lighting and a 60-Amp DC alternator for charging batteries. The entire system can be built at a cost of P90,000.00 (USD1 = PHP50) using local materials and skills. Analysis showed that the operating cost of the gasifier is only P94.15 per day. A savings 0 P244.94 per day can be derived against the use of purely gasoline fuel for the engine. Payback period is 1.22 years.
\end{abstract}

\section{Subject Areas}

Agricultural Engineering

\section{Keywords}

Biomass Gasification, Biomass Power Generation, Rice Husk Gasifier 


\section{Introduction}

With the enactment of the Agricultural and Fishery Mechanization Act (AFMech) in 2014, the level of farm mechanization in the Philippines has increased from $0.52 \mathrm{hp} / \mathrm{ha}$ in the mid 90's [1] to $2.31 \mathrm{hp} / \mathrm{ha}$ in 2013 [2]. However, with the growing number of agricultural machines in the country and continuous depleting supply of fossil fuel, there must be an alternative solution to address this problem.

Rice-based biomass, consisting of rice husks and straws, is a potential source of energy to provide power for agricultural machinery [3]. Rice husk is $20 \%$ of paddy while rice straw is 5 times more than rice husk. Converting them into fuel through gasification makes possible the use of these resources into energy to produce mechanical power for various farming tasks. The by-product, which is char, can be utilized in the farm to condition the soil as well as to sequester carbon for greenhouse gas mitigation.

Gasifier technology for biomass like rice husk has been developed ranging from a simple batch-type to a continuous-type reactor [3]. The technology looks complicated since it consists of varying sizes of cylinders with gas and liquid moving devices. Gasification simply requires proper sizing of the diameter of the reactor cylinder in combination with selecting the right size of an air-moving device in order to generate combustible gas. Once cleaned and cooled, the gas can be used as fuel for spark ignition engine in driving stationary agricultural machines as well as generator/alternator to produce electricity.

By using locally-available surplus-oil and -petrol drums commonly found along the roadsides outside Metro Manila, like Bulacan and Nueva Ecija, a gasifier can be made as simple as possible where even farmers and/or local people can build it themselves. There is no need for them to buy new engine because they can utilize their existing one by just adding pipes and valves in order to retrofit it to be able to utilize the gas they produced from the gasifier.

This study aimed to develop an appropriate rice-based biomass (ARB) gasifier as source of power for farm use. Specifically, it aimed to: 1) determine the gasification properties of rice-biomass required in the design of ARB gasifier, 2) design, build, and develop the gasifier that can run small spark ignition engines using locally available materials and skills in fabrication, 3) test and evaluate the performance characteristics of the gasifier as well as its ability in powering small agricultural machines, and 4) analyze the operating cost and determine the payback period of the gasifier.

\section{Review of Literature}

Rice husk is around $20 \%$ of paddy harvested while rice straw is 5 times more than rice husk [4]. A kilogram of rice husk contains $3000 \mathrm{kcal}$ energy and it can provide $1.2 \mathrm{~m}^{3}$ of combustible gases containing carbon monoxide (CO), hydrogen $\left(\mathrm{H}_{2}\right)$, and methane $\left(\mathrm{CH}_{4}\right)$ when gasified [5]. The gas produced is known as "producer gas" which can be used as fuel either for heating in gas burners or in 
running internal combustion engine [6]. In comparison, rice straw has a slightly lower heating value and ash content than rice husks [7]. It is loosely dense and burns faster compared with rice husks. Reducing the size of rice straw or densifying it to make it harder can make it possible to be used as fuel for gasifiers [8].

There are different methods of gasifying rice husks which can also be adopted for rice straw. These include: fixed-bed, moving-bed, and fluidized-bed gasification operating either by downdraft or updraft mode [9] [10]. Of these methods, however, the fixed- and the moving-bed gasifiers are the simplest and are applicable especially for micro- to small-scale gasification system since the fuel is just placed in a container called reactor, where partial burning of biomass is accomplished to produce gas. By operating the gasifier on a downdraft mode, clean gas can be derived with minimal amount of tar or particulates. Cleaning the gas by scrubbing and filtering can make it a suitable fuel for internal combustion engines.

The University of California (UC) Davis designed and developed a small-scale rice husk gas producer for engine operation in mid 80's [11]. It employs a double-core, down-draft type, dual reactor for continuous operation with gas cleaning train in order to fuel engine. A 5-hp, single cylinder, gasoline engine was successfully operated on producer gas with a centrifugal pump for a period of 9 hrs. A small-scale, downdraft rice hull gas producer was also tested at UC Davis to determine its technical feasibility and to identify its optimal operating parameters [12]. Their results showed that the power output of the engine at rated speed was $43 \%$ with brake thermal and overall system efficiencies of $16.8 \%$ and 9.4\%, respectively. At PhilRice, a batch-type, dual core, downdraft gasifier reactor for pumping water was designed and tested in 2008 [13]. The gasifier is a mobile unit equipped with wet scrubbers and dry packed-bed filters. Water can be pumped from an open source at a rate of $7.5 \mathrm{lps}$, with $1.3-\mathrm{m}$ head using only 4 $\mathrm{kgs}$ of rice husk for a period of $1.35 \mathrm{hr}$. A rice husk gasification system for electricity generation and for char production was developed at PhilRice in the mid of 2000's [14]. The gasifier as reported can generate 8 to $12 \mathrm{~kW}$ at a rice husk consumption rate of 20 to $30 \mathrm{~kg}$ per hour. Gas flow rate was measured at 30 to 40 cubic meter per hour. The char conversion rate was around 25\%, depending on the operating condition of the gasifier.

Moreover, a moving-bed downdraft rice husk gasifier that allows continuous operation in a single reactor was developed in the Philippines [15] [16]. By coupling a gas conditioning equipment to the gasifier reactor, clean gas is derived from the rice husks being gasified which can be used as fuel for internal combustion engine.

\section{Methodology}

\subsection{Determination of the Gasification Properties of Fuel}

Figure 1 shows the $15 \mathrm{~cm}$-diameter by $70 \mathrm{~cm}$-height gasifier reactor test rig which was built to determine the gasification properties of rice husks and rice 

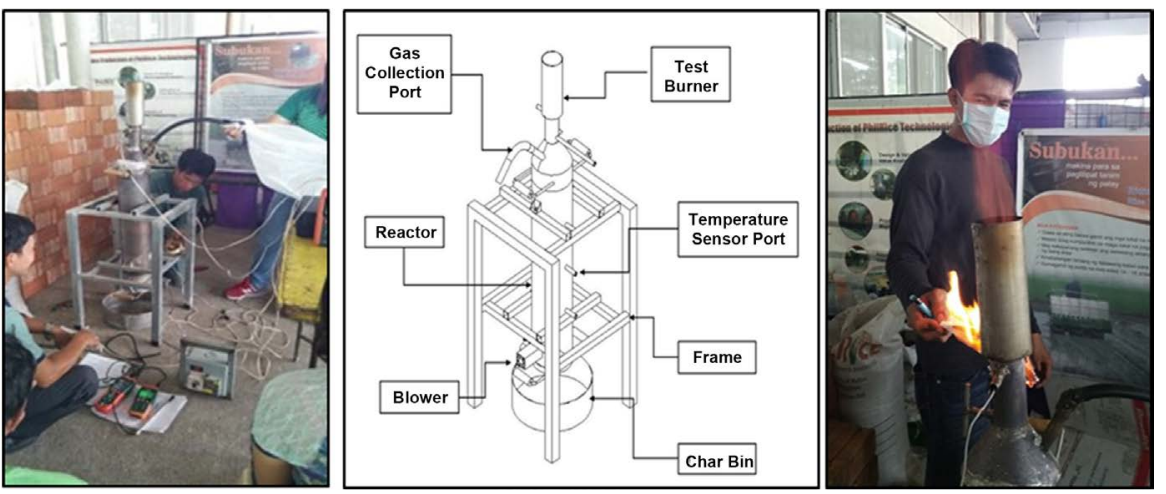

Figure 1. The gasifier reactor test rig used in the study.

straws as to their potential as fuel for the gasifier. Fresh or new rice husks obtained from a rice mill near PhilRice was used as samples; whereas for rice straw, threshed panicles and stubbles left in the field for a month were used. The rice straw samples were cut into small sizes of around 6- to 10-mm in length. All the samples were placed in a room for a week to allow their moisture to equilibrate before they were subjected in the test rig. Determination of the gasification properties of the different samples were carried out at an airflow rate in which burning flames are visibly observed at the burner of the test rig. The data needed such as weight of samples and char produced, operating time, temperature of gas and temperature at the fuel bed, velocity of air entering the reactor, as well as static pressure were all gathered. Parameters analyzed include: 1) Bulk density; 2) Air/Fuel ratio; 3) Superficial gas velocity; 4) Specific gasification rate; 5) Specific draft; 6) Reactor bed temperature; and 7) Gas temperature. The percentage composition of $\mathrm{CO}, \mathrm{H}_{2}, \mathrm{CH}_{4}, \mathrm{CO}_{2}, \mathrm{C}_{\mathrm{n}} \mathrm{H}_{\mathrm{m}}, \mathrm{O}_{2}$, and lower heating value of gas were also determined.

\subsection{Design Criteria, Calculation, Concept, and Drawing Preparation}

A conceptual design of the ARB gasifier was prepared considering the following criteria: 1) primary materials for the gasifier unit should utilize 50 liter- and 200 liter-capacity salvage petrol drums; 2) plastic pipes must be used to convey the gas; 3) use of GI pipes, bars and sheets must be minimal and use of locally-available standard parts of the machine; 4) tools for fabrication of the gasifier must be readily available; 5) standard parts, such as pump and suction blower, must be available from the local suppliers; and 6) 16 - $22 \mathrm{Hp}$ single-piston spark-ignition engine commonly available in the farm must be used.

The conceptual design and calculations for the size of the gasifier components were prepared including the drawings and list of materials to build a prototype unit.

\subsection{Fabrication, Modification, and Improvement}

The prototype unit of the gasifier was fabricated based on the design drawing 
provided to the shop technician at Rice Engineering and Mechanization Division at PhilRice Central Station. Regular monitoring was done to ensure that the gasifier is fabricated according to the design drawing. After each part was built, they were all coupled together to complete the entire unit for series of functional tests, modification and improvement.

\subsection{Performance Testing and Evaluation}

Performance testing and evaluation of the gasifier built were carried out in selected field sites. The gasifier was run with only the pump and the blower are attached to it as load to determine its performance characteristics. Different machines were attached to see whether the gasifier is capable in driving the loads. The following were determined during the tests: 1) Amount of fuel used;2) Operating time; 3) Gas flow rate; 4) Temperature at different locations in the system; 5) Engine speed and sound level; 6) Gas quality $\left(\mathrm{CO}, \mathrm{H}_{2}, \& \mathrm{CH}_{4}\right)$; 7) Output of the machine coupled to the engine; and 8) Amount of char produced.

The weight of fuel and the weight of char produced were measured using a $20-\mathrm{kg}$ spring balance. A probe-type moisture meter was used in determining the moisture content of the samples. The time to ignite the fuel and to generate combustible gas as well as the total time of operation were recorded using a Digital Stopwatch. Temperature at the different sections of the gasifier was taken using a Type-K thermocouple-wire sensors attached to a digital thermometer (EXTECH Thermocouple Datalogger Model TM500) and by a RICK Dial-type Thermometer $\left(0^{\circ} \mathrm{C}-150^{\circ} \mathrm{C}\right)$. The volumetric flow rate of gas entering the engine was determined by measuring the velocity of the gas in the pipe leading to the engine using EXTECH Hot Wire Thermo-anemometer Model SDL 350 multiplied by the cross-sectional area of the pipe. The composition and the heating value of the gas entering the engine were also taken using Amperis Gas Analyzer Transdox 5100B. In measuring the water flow rate at the scrubber, a rotary flow meter was attached to the intake pipe of the scrubber. The speed of the pump, of the blower, and of the engine drive shaft were all taken using an EXTECH Laser Photo Tachometer Model RPM33. The sound released by the engine was measured at 1.5-m high and at 1-m distance from the engine muffler using an AZ Digital Sound Level Meter Model 8928. The $\mathrm{pH}$ measurement of water in the pond was taken with the use of $\mathrm{AZ} \mathrm{pH}$ meter 8684 .

From the data gathered, the following parameters were analyzed: 1) Fuel Consumption Rate; 2) Specific Gasification Rate; 3) Gas Flow Rate; 4) Fuel/Gas Ratio; 5) Fire Zone Rate; 6) Superficial Gas Velocity; 7) Water/Gas Ratio; and 8) Percentage Char Produced.

\section{Results and Discussion}

\subsection{Gasification Properties of Rice Biomass}

Table 1 shows the results of the tests on gasification properties of rice husk and rice straw samples that are relevant to the design of the gasifier. In terms of 
Table 1. Results of the gasification tests of rice husk and rice straw samples in the test rig.

\begin{tabular}{lccc}
\hline & Rice Husks & Rice Straw Panicles & Rice Straw Stubbles \\
\hline Bulk Density, kg/m ${ }^{3}$ & $101-104$ & $45-51$ & $57-59$ \\
Air-Fuel Ratio, kg air/kg fuel & $0.88-1.09$ & $0.56-0.68$ & $0.97-1.08$ \\
Superficial Gas Velocity, cm/sec & $2.26-4.86$ & $1.47-1.86$ & $2.12-3.32$ \\
$\begin{array}{l}\text { Specific Gasification Rate, } \\
\text { kg/hr-m }{ }^{2}\end{array}$ & $115.8-199.9$ & $117.3-123.4$ & $120.3-138.2$ \\
Specific Draft, mm $\mathrm{H}_{2} \mathrm{O} / \mathrm{m}$ & $6.22-19.40$ & $2.74-2.86$ & $4.48-9.40$ \\
Reactor Fuel-Bed Temperature, ${ }^{\circ} \mathrm{C}$ & $416-477$ & $625-735$ & $625-738$ \\
Gas Temperature, ${ }^{\circ} \mathrm{C}$ & $247-259$ & $218-268$ & $223-314$ \\
Char Produced, $\%$ & $28.6-31.3$ & $14.3-27.7$ & $27.2-30.3$ \\
\hline
\end{tabular}

bulk density, which is the determining factor for the size of the reactor of the gasifier. Rice husk has higher bulk density which is almost double of that of rice straw panicles and rice straw stubbles with 101 to $104 \mathrm{~kg} / \mathrm{m}^{3}, 45$ to $51 \mathrm{~kg} / \mathrm{m}^{3}$ and 57 to $59 \mathrm{~kg} / \mathrm{m}^{3}$, respectively. In terms of the amount of air required per amount of fuel to be used, results showed that rice husk uses more air (0.88 to 1.09) to gasify than rice straw (0.56 to 1.08). The superficial velocity of gas in the fuel bed, which is an indicator of hole formation in the fuel bed, ranges from 2.26 to $4.86 \mathrm{~cm} / \mathrm{sec}$ for rice husk, from 2.12 to $3.32 \mathrm{~cm} / \mathrm{sec}$ for rice straw stubbles, and from 1.47 to $1.86 \mathrm{~cm} / \mathrm{sec}$ for rice straw panicles. Holes formation in the fuel bed must be prevented during operation for it reduces the quality of gas produced. The specific gasification rate, which is usually used in determining the diameter of the reactor, is higher for rice husk than that for rice straw samples. Rice husks operate at a specific gasification rate at a range of 115.8 to $199.9 \mathrm{~kg} / \mathrm{hr}-\mathrm{m}^{2}$ while for rice straw panicles and stubbles are at the range of 117.3 to $123.4 \mathrm{~kg} / \mathrm{hr}-\mathrm{m}^{2}$ and 120.3 to $138.2 \mathrm{~kg} / \mathrm{hr}-\mathrm{m}^{2}$, respectively. In terms of specific draft, which is used to determine the pressure draft requirement of the blower for the gasifier, rice husk samples obtain a higher value ( 6.22 to $19.40 \mathrm{~mm} \mathrm{H}_{2} \mathrm{O}$ per meter) than that of rice straw samples, which is 2.74 to $2.86 \mathrm{~mm} \mathrm{H}_{2} \mathrm{O}$ per meter for rice straw panicles and 4.48 to $9.40 \mathrm{~mm} \mathrm{H}_{2} \mathrm{O}$ per meter for rice straw stubbles.

With regard to the temperature at the fuel bed in the reactor, rice husk has lower temperature $\left(416^{\circ} \mathrm{C}\right.$ to $\left.477^{\circ} \mathrm{C}\right)$ than rice straw samples $\left(625^{\circ} \mathrm{C}\right.$ to $735^{\circ} \mathrm{C}$, and $625^{\circ} \mathrm{C}$ to $738^{\circ} \mathrm{C}$ rice straw panicles and rice straw stubbles, respectively).It implies that rice straws, having low bulk density, burn easily than rice husks. Moreover, the slightly higher temperature of the gas leaving the reactor with rice straws $\left(218^{\circ} \mathrm{C}\right.$ to $\left.314^{\circ} \mathrm{C}\right)$ than with rice husks $\left(247^{\circ} \mathrm{C}\right.$ to $\left.259^{\circ} \mathrm{C}\right)$ is likewise indicative of more burning of rice straw samples as compared with rice husk samples. As a result, lesser amount of char produced is obtained for rice straw panicles (14.3\% to $27.7 \%)$ and for rice straw stubbles $(27.2 \%$ to $30.3 \%)$ than that of rice husks (28.6\% to $31.3 \%)$.

Results in the composition of gases derived from the samples tested, Table 2 
shows that gasified rice husks contains a relatively higher carbon monoxide gas (13.20\% to $14.41 \%$ ) compared with rice straw samples of only $6.08 \%$ to $7.81 \%$ for panicles and $8.81 \%$ to $8.88 \%$ for stubbles. The amount of methane gas is almost the same for the three samples with $1.43 \%$ to $1.88 \%, 1.19 \%$ to $1.58 \%$ and $1.62 \%$ to $1.81 \%$ for rice husk, rice straw panicles and rice straw stubbles, respectively. Hydrogen gas is quite high for rice husk (6.10\% to $6.13 \%)$ than that for rice straw samples. Moreover, rice straw panicles contain lower hydrogen gas $(1.35 \%$ to $2.94 \%)$ than that of rice straw stubbles $(3.12 \%$ to $4.11 \%)$. For non-combustible gases, the amount of carbon dioxide gas obtained ranges from $11.70 \%$ to $12.09 \%$ for rice husks, $12.81 \%$ to $13.15 \%$ for rice straw panicles, and $12.00 \%$ to $13.03 \%$ for rice straw stubbles. On the other hand, the amount of $\mathrm{C}_{\mathrm{n}} \mathrm{H}_{\mathrm{m}}$ gas, which is indicative of the presence of hydrocarbons such as tars, is lower for rice husk $(0.04 \%$ to $0.06 \%)$ than that for rice straw samples $(0.15 \%$ to $0.16 \%$ for panicles and $0.10 \%$ to $0.20 \%$ for stubbles). Furthermore, the amount of oxygen gas is much lower for rice husk ( $0.61 \%$ to $0.79 \%)$ compared with rice straw panicles (4.20\% to $5.12 \%$ ) and rice straw stubbles (3.54\% to $4.69 \%)$. From the results, the computer calculated values for the lower heating value of gas is highest for rice husks $\left(695\right.$ to $763 \mathrm{kcal} / \mathrm{m}^{3}$ ) followed that for rice straw stubbles $\left(527\right.$ to $535 \mathrm{kcal} / \mathrm{m}^{3}$ ) and is lowest that for rice straw panicles (346 to 470 $\mathrm{kcal} / \mathrm{m}^{3}$ ). Results on the heating value of gas shows that rice husk is more advantageous to use as fuel for the ARB gasifier than rice straws, which need to be cut into smaller pieces.

\subsection{Design Description of the ARB Gasifier}

The design development of the gasifier unit underwent step-by-step processes until the final ARB gasifier was fully developed. Figure 2 \& Figure 3 show the gasifier finally developed. As shown, it consists of the following major components: 1) Fuel Reactor; 2) Gas Conditioning Device; 3) Water Cooling Pond; and 4) Power Generating Device.

Table 2. Composition of gases derived from the test rig for rice husk and rice straw samples.

\begin{tabular}{cccc}
\hline & Rice Husk & Rice Straw Panicles & Rice Straw Stubbles \\
\hline Carbon Monoxide $(\mathrm{CO}), \%$ & $13.20-14.41$ & $6.08-7.81$ & $8.81-8.88$ \\
Methane $\left(\mathrm{CH}_{4}\right), \%$ & $1.43-1.88$ & $1.19-1.58$ & $1.62-1.81$ \\
Hydrogen $\left(\mathrm{H}_{2}\right), \%$ & $6.10-6.13$ & $1.35-2.94$ & $3.12-4.11$ \\
Carbon Dioxide $\left(\mathrm{CO}_{2}\right), \%$ & $11.70-12.09$ & $12.81-13.15$ & $12.00-13.03$ \\
Hydro Carbon $\left(\mathrm{C}_{\mathrm{n}} \mathrm{H}_{\mathrm{m}}\right), \%$ & $0.04-0.06$ & $0.15-0.16$ & $0.10-0.20$ \\
Oxygen $\left(\mathrm{O}_{2}\right), \%$ & $0.61-0.79$ & $4.20-5.12$ & $3.54-4.69$ \\
Lower Heating Value, $\mathrm{kcal} / \mathrm{m}^{3}$ & $695-763$ & $346-470$ & $527-535$ \\
\hline
\end{tabular}




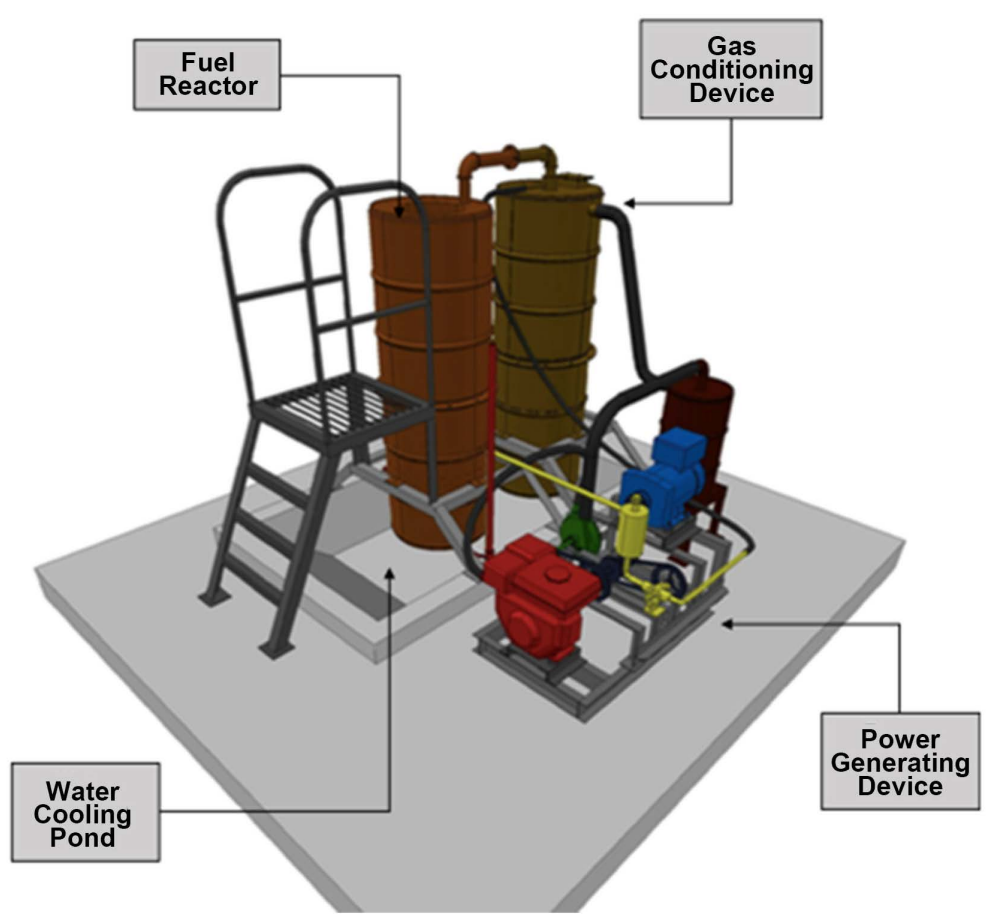

Figure 2. The perspective drawing of the ARB gasifier unit showing major components.

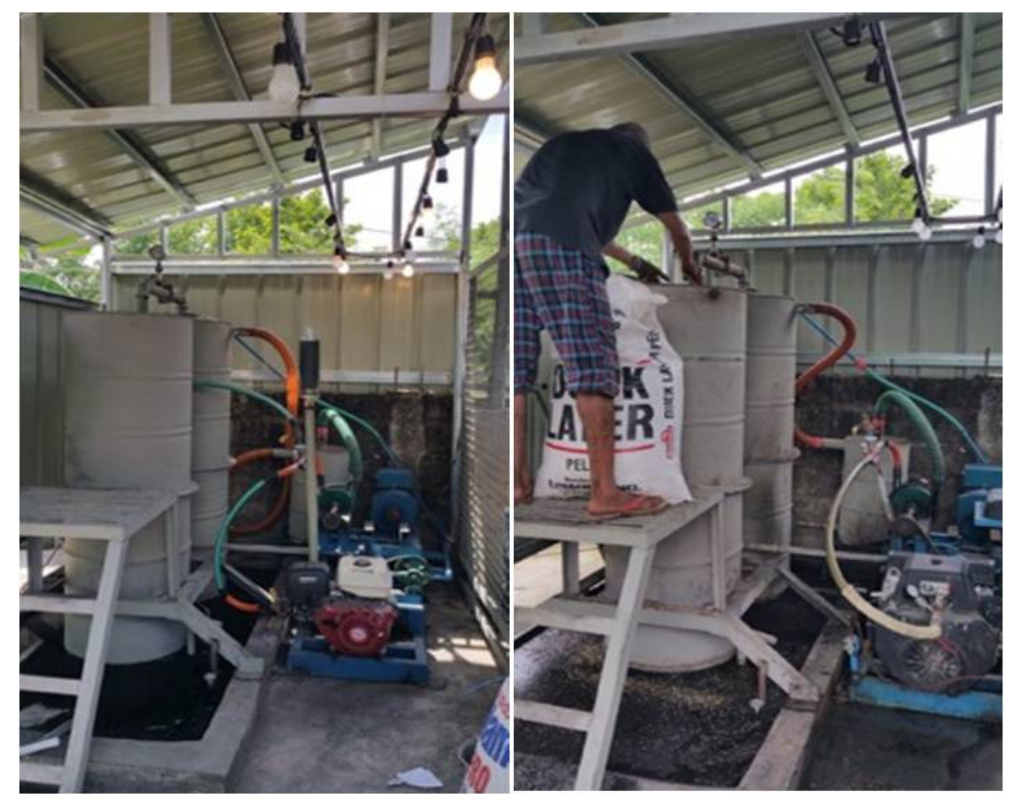

Figure 3. Pictorial of the ARB gasifier.

The reactor serves as the gas generating component of the system. It is where rice-based biomass undergoes thermochemical reaction to produce combustible gases which can be used as fuel for an internal combustion engine. Two $35 \mathrm{~cm}-\phi$ by $60 \mathrm{~cm}$-long grease drums are used as inner cylinder for the reactor. A locally-mixed refractory cement was used as insulation, with 5-cm thickness, for the drums. On the other hand, two petrol drums (200-liter cap per drum), each 
having $60-\mathrm{cm} \phi$ by $90-\mathrm{cm}$ high, are used as outer cylinder for the reactor. During development, flanges are provided for the drums to facilitate repair and improvement work. The inner cylinder drum is centrally welded at the top portion of the outer cylinder drum. A $2 \frac{1}{2}-$-in. $\phi$ by 20 -cm high GI pipe is welded at the annular space between the inner and outer cylinders serving as gas outlet. Beneath the inner cylinder is a char discharge mechanism designed to temporarily hold burned rice husks in pockets for a gradual discharge of the char during operation.

The gas conditioning device serves as the cleaning, cooling and storage component for the gas produced from the reactor. It is made of two drums welded end-to-end having 60- $\mathrm{cm} \varphi$ and 1.8-mtotal height. A cross-flow scrubber, which is attached to the reactor, is installed at the top of the gas conditioning cylinder. It is made of a 4 in.- $\phi$ by $120 \mathrm{~cm}$-high pipe serving as outer casing and a $2 \frac{1}{2}-$-in. pipe, with $3 \mathrm{~mm}-\phi$ holes at the periphery, as inner casing. Water is forced to the annular space of the pipes by a $1 / 2$-in. gear pump to create spray water for the gas. A $6 \mathrm{~mm}-\phi$ perforated sheet is installed at the middle of the gas conditioning cylinder to hold the filter materials, which is made of crushed stones $(6 \mathrm{~mm}$ - to 10 $\mathrm{mm}-\phi)$, to mechanically screen the gas. The gas exits from the top of the gas conditioning cylinder through a $2 \frac{1}{2}-$-in. $\phi$ pipe leading to a smaller drum serving as gas storage and, at the same time, to allow the water that goes with the gas to drip.

The water cooling pond, on the other hand, is where the reactor and gas conditioning device seats through an angular support frame. The water in the pond seals the bottom end of the reactor and quenches burning of discharged char. It is constructed on ground using pure concrete or, in some cases, using metal sheets with $120 \mathrm{~cm}$-wide by $150 \mathrm{~cm}$-long and $50 \mathrm{~cm}$-deep dimension.

The power generating device converts the gas produced into mechanical power with the use of 16-hp, 17-hp, or 22-hp, 4-stroke-cycle, spark ignition engine.

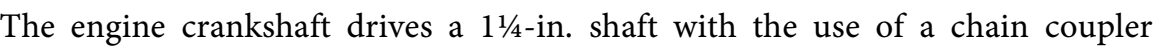
where the suction blower and gear pump are being driven by means of belt and pulley. The blower is directly coupled to a 2 in.- $\phi$ plastic hose to suck the gas from the reactor and from the gas conditioning unit and deliver it into the intake manifold of the engine.

Figure 4 shows the schematic diagram of the principle of operation of the ARB gasifier. Basically, the gasifier unit operates on a moving-bed down draft mode. Rice-based biomass fuel are fed into the reactor to undergo thermochemical process in order to produce combustible gases, that are rich in carbon monoxide $(\mathrm{CO})$, methane $\left(\mathrm{CH}_{4}\right)$, and hydrogen $\left(\mathrm{H}_{2}\right)$. Ignition of fuel starts at the bottom through the suction created by the blower. Air enters from the top of the reactor and passes through the burning layer of biomass fuel at a controlled rate. The gas produced exits from the bottom of the reactor inner cylinder and passes through the annular space between the inner and outer cylinders and leaves through the pipe installed at the top of the reactor. The gas enters the gas conditioning unit passing through spray water. Particulates, such as fly ashes and tars, 


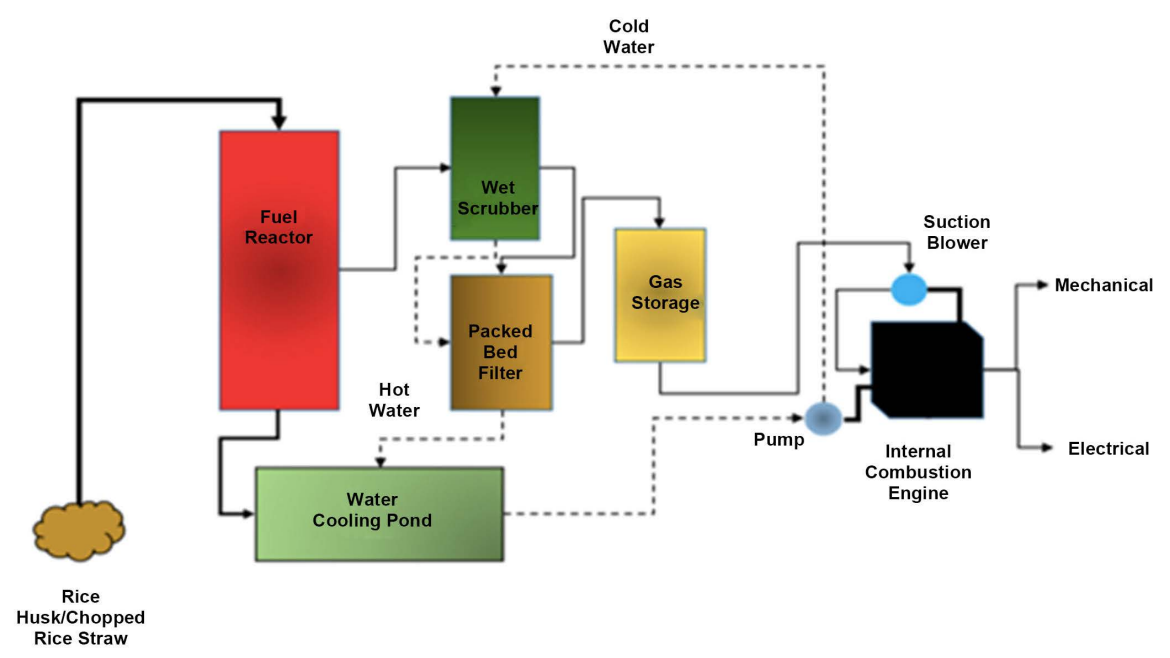

Figure 4. Schematic diagram of the principle of operation of the ARB gasifier.

are removed when the gas passes through spray water. The spray water also reduces the temperature of the gas before it enters the intake manifold of the engine. Solid and liquid particles that go with the gas are filtered as the gas passes through the layers of crushed stones. The gas then exits from the gas conditioning unit and to the gas storage to further remove some water from it before it enters the engine. The power produced by the engine is used to provide the parasitic load as well as to drive stationary agricultural machines.

\subsection{Performance Characteristics}

Table 3 shows the performance characteristics of the ARB gasifier unit. Tests carried out for 3 runs using rice husks as fuel with blower and pump as load. For the three test runs made, one full load of biomass fuel in the reactor requires 16.0 to $17.1 \mathrm{~kg}$ of rice husks, with $9 \%$ to $13 \%$ moisture, to sustain continuous for at least more than an hour. It took 5 to 6 minutes to ignite and attain $80 \%$ full ignition of fuel in the reactor bed. Combustible gas is produced and becomes ready to be fed into the engine within 5 to 11 minutes after ignition of fuel. From the time the gas is used by the engine until it stops, i.e., consuming the one full load of rice husks, the total recorded period ranges from 1.46 to 1.63 hours. Measurement of shaft speed showed that the engine crankshaft rotates at a speed between 2445.5 to $2633.9 \mathrm{rpm}$; whereas the blower speed and the pump run between 5813.5 to $7238.3 \mathrm{rpm}$ and 866.9 to $1081.8 \mathrm{rpm}$. On the other hand, the amount of gasoline fuel consumed by the engine to start-up and shut-off the gasifier varies from 0.4 to 0.8 liter.

Measurement of the noise level emanating from the engine muffler ranges from 87.2 to $92.4 \mathrm{~dB}$. These values indicate that there is no need to install a silencer in order to deaden the noise of the engine. The $\mathrm{pH}$ values in the water pond, measured at the start and at the end of operation, range from 7.6 to 9.0 and from 7.6 to 8.4 , respectively, indicating that there is a slight change in the acidity of water. Only 1 operator is required to operate the entire system which includes loading of fuel and unloading of char. 
Table 3. Performance characteristics of the ARB gasifier using rice husk as fuel.

\begin{tabular}{|c|c|c|c|}
\hline & Run 1 & Run 2 & Run 3 \\
\hline Weight of Fuel Used (kg) & 16.0 & 17.1 & 16.5 \\
\hline Moisture Content (\%) & 13 & 9 & 11 \\
\hline Start-Up (min) & 5 & 6 & 5 \\
\hline Gas Generation Time (min) & 10 & 11 & 5 \\
\hline Total Operating Time (hr) & 1.46 & 1.63 & 1.55 \\
\hline \multicolumn{4}{|l|}{ Shaft Speed (rpm) } \\
\hline Engine & 2445.5 & 2631.7 & 2633.9 \\
\hline Blower & 5813.5 & 7238.3 & 6804.5 \\
\hline Pump & 866.9 & 1081.4 & 1081.8 \\
\hline Volume of Gasoline Used (liter) & 0.8 & 0.5 & 0.4 \\
\hline Sound $(\mathrm{dB})$ & 92.4 & 91.8 & 87.2 \\
\hline $\mathrm{pH}$ Start & 9.0 & 8.0 & 7.6 \\
\hline End & 8.4 & 7.6 & 7.7 \\
\hline Number of Operator & 1 & 1 & 1 \\
\hline Fuel Consumption Rate (kg/hr) & 10.91 & 10.47 & 10.65 \\
\hline Specific Gasification Rate $\left(\mathrm{kg} / \mathrm{hr}-\mathrm{m}^{2}\right)$ & 154.34 & 148.12 & 150.67 \\
\hline Gas Flow Rate $\left(\mathrm{m}^{3} / \mathrm{hr}\right)$ & 5.47 & 7.34 & 7.17 \\
\hline Fuel/Gas Ratio (kg fuel/ $\mathrm{m}^{3}$ of gas) & 1.99 & 1.43 & 1.48 \\
\hline Fire Zone Rate (cm/min) & 0.88 & 0.99 & 1.17 \\
\hline Superficial Gas Velocity $(\mathrm{cm} / \mathrm{s})$ & 1.56 & 2.10 & 2.05 \\
\hline Water/Gas Ratio (liter/m³ of gas) & 37.04 & 58.38 & 45.86 \\
\hline Gasification Efficiency (\%) & 13.15 & 18.81 & 17.87 \\
\hline
\end{tabular}

Table 3 also shows the different gasifier parameters. As shown, the computed amount of rice husk consumed by the gasifier for the three test runs ranges from 10.47 to $10.91 \mathrm{~kg}$ per hour. With $0.30 \mathrm{~m}$-diameter reactor, the computed specific rate ranges from 148.12 to $154.34 \mathrm{~kg} / \mathrm{hr}-\mathrm{m}^{2}$, which conforms with the value range obtained from the test rig. Based on the measured velocity using a thermo-anemometer and on the cross-sectional area of the gas pipe, the computed amount of gas entering the engine is at the range of 5.47 to $7.34 \mathrm{~m}^{3} / \mathrm{hr}$. From this result, the computed fuel/gas ratio ranges from 1.43 to $1.99 \mathrm{~kg}$ of rice husk per $\mathrm{m}^{3}$ of gas. The computed upward movement of fire zone ranges from 0.88 to $1.17 \mathrm{~cm}$ per min. This means that char disposal must be done once in a while if prolonged operation is desired. The computed superficial gas velocity ranges from 1.56 to $2.10 \mathrm{~cm}$ per second, which is slightly below than the result from the test rig. The computed volume of water used at the scrubber per $\mathrm{m}^{3}$ of gas ranges from 37.04 to 58.38 liters. Gasification efficiency, which is computed based on the energy produced from the gas after scrubbing to the amount of energy in the 
fuel, ranges from $13.15 \%$ to $18.81 \%$.

Figure 5 shows the temperature profile of the gasifier in one run. As shown, the reactor bed, where fuel is burned, is the hottest part of the gasifier. As the gas travels from the reactor to the engine, the gas temperature decreases by around $30^{\circ} \mathrm{C}$ to $38.8^{\circ} \mathrm{C}$.

Table 4 gives the percentage composition of gases produced from the gasifier during the tests. The amount of CO obtained is at the range of $9.370 \%$ to 9.592\%. For $\mathrm{H}_{2}$, the gas composition obtained ranges from $3.378 \%$ to $4.502 \%$. Also, composition of $\mathrm{CH}_{4}$ obtained ranges from $3.476 \%$ to $3.958 \%$. For non-combustible gases like $\mathrm{CO}_{2}$, it ranged from $4.418 \%$ to $5.038 \%$ while $\mathrm{O}_{2}$ ranges from $7.564 \%$ to $8.380 \%$. The lower heating value of gas was measured ranging from 2.976 to $3.004 \mathrm{MJ} / \mathrm{m}^{3}$.

\subsection{Performance with Driven Machines}

Table 5 summarizes the performance of the gasifier with driven machines. As shown, for the 4-in. centrifugal self-priming pump commonly used by farmers, the $17 \mathrm{hp}$ Yamamoto engine can drive the pump at a rate of $30.37 \mathrm{~m}^{3} / \mathrm{hr}$ on a head of $1.2 \mathrm{~m}$ using rice husks as fuel. The amount of rice husks consumed was $7.3 \mathrm{~kg}$ per hour on a 4 -hour test. Using rice straw as fuel, at $15.71 \mathrm{~m}^{3} / \mathrm{hr}$ of water pumped at a head of $1.1 \mathrm{~m}$, the amount of fuel used was $8.5 \mathrm{~kg}$ per hour on 0.5 -hour test. The short test result can be attributed to the problem of continuous feeding as well as clogging of fuel in the reactor during operation. On the other hand, a 16-hp Daikin engine can drive a $30 \mathrm{~cm}$-diameter biomass chipper producing 4- to 20 - $\mathrm{mm}$ diameter "madre de cacao" chips at a rate of $53 \mathrm{~kg}$ per hour. Rice husk fuel consumed is $10.1 \mathrm{~kg}$ per hour for 2.1 hour. Using ipil-ipil twigs and branches of $6-\mathrm{mm}$ to $15-\mathrm{mm}$ sizes, the gasifier can drive the machine

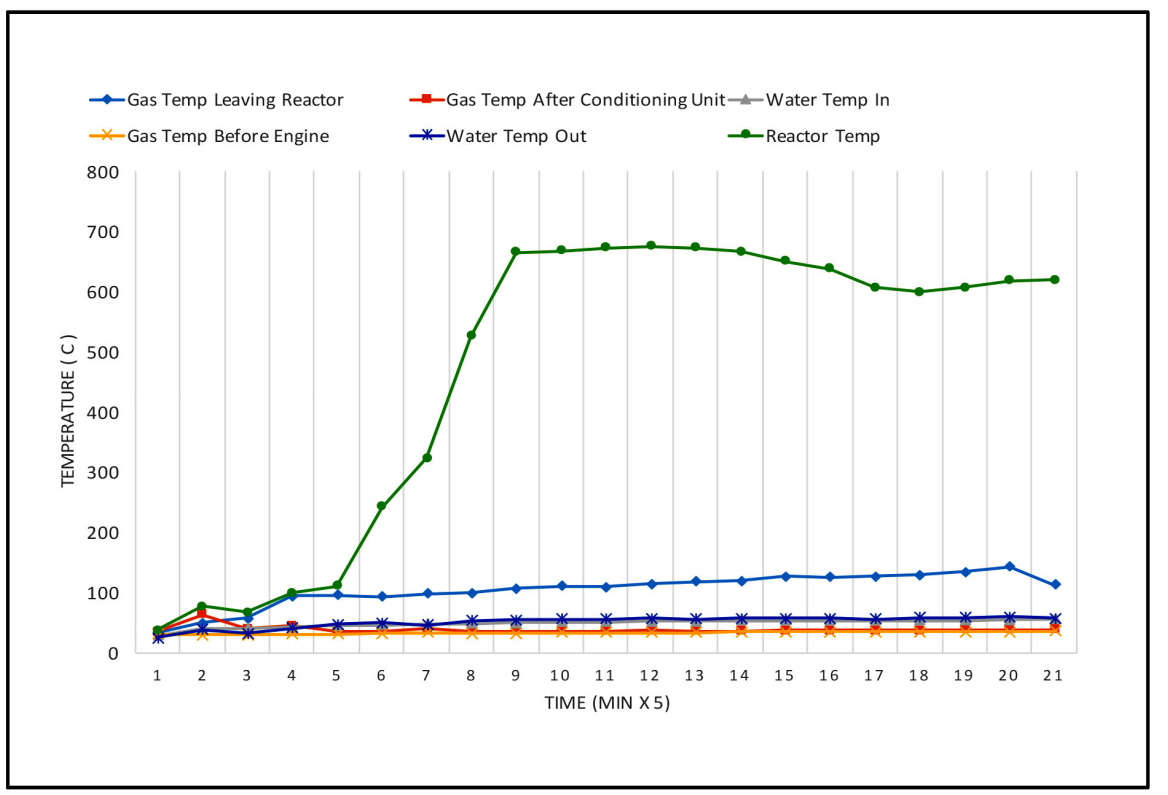

Figure 5. Temperature profile of ARB gasifier in one of the runs. 
Table 4. Compositions of producer gas obtained from the ARB gasifier unit.

\begin{tabular}{ccccccc}
\hline Run & $\begin{array}{c}\mathrm{CO} \\
(\%)\end{array}$ & $\begin{array}{c}\mathrm{H}_{2} \\
(\%)\end{array}$ & $\begin{array}{c}\mathrm{CH}_{4} \\
(\%)\end{array}$ & $\begin{array}{c}\mathrm{CO}_{2} \\
(\%)\end{array}$ & $\begin{array}{c}\mathrm{O}_{2} \\
(\%)\end{array}$ & $\begin{array}{c}\mathrm{LHV} \\
\left(\mathrm{MJ} / \mathrm{m}^{3}\right)\end{array}$ \\
\hline 1 & 9.372 & 3.378 & 3.958 & 5.038 & 7.564 & 2.976 \\
2 & 9.412 & 4.008 & 3.902 & 4.418 & 8.380 & 3.044 \\
3 & 9.592 & 4.502 & 3.476 & 4.490 & 8.278 & 3.008 \\
\hline
\end{tabular}

*Average of the samples of gases taken at the start, middle, and end of the operation.

Table 5. Performance of the gasifier with attached machines.

\begin{tabular}{|c|c|c|c|c|c|}
\hline Machine & Engine & Fuel & Load & $\begin{array}{l}\text { Fuel Consumption } \\
\text { Rate }(\mathrm{kg} / \mathrm{hr})\end{array}$ & $\begin{array}{c}\text { Time Operated } \\
(\mathrm{hr})\end{array}$ \\
\hline \multirow[t]{2}{*}{$\begin{array}{c}\text { Centrifugal Self } \\
\text { Priming Pump } 4 \text { in. }\end{array}$} & Yamamoto $17 \mathrm{hp}$ & Rice husk & $\mathrm{Q}=30.27 \mathrm{~m}^{3} / \mathrm{hr} @ \mathrm{H}=1.2 \mathrm{~m}$ & 7.3 & 4.0 \\
\hline & Yamamoto $17 \mathrm{hp}$ & Rice Straw & $\mathrm{Q}=15.71 \mathrm{~m}^{3} / \mathrm{hr} @ \mathrm{H}=1.1 \mathrm{~m}$ & 8.5 & 0.5 \\
\hline \multirow[t]{2}{*}{$\begin{array}{c}\text { Biomass Chipper } 30 \\
\text { cm Disk }\end{array}$} & Daikin $16 \mathrm{hp}$ & Rice husk & $\begin{array}{c}53 \mathrm{~kg} \text { of madre de cacao twigs and } \\
\text { branches ( } 4 \mathrm{~mm} \text { to } 20 \mathrm{~mm} \mathrm{D}) \text { per hour }\end{array}$ & 10.1 & 2.1 \\
\hline & Daikin $16 \mathrm{hp}$ & Rice Husk & $\begin{array}{l}16.9 \mathrm{~kg} \text { of ipil-ipil twigs and branches } \\
(6 \mathrm{~mm} \text { to } 10 \mathrm{~mm} \mathrm{D}) \text { per hour }\end{array}$ & 11.5 & 2.5 \\
\hline $\begin{array}{l}\text { Rubber Creeping Mill } \\
\text { Double roller } 15 \mathrm{~cm} \mathrm{D}\end{array}$ & Yamamoto $17 \mathrm{hp}$ & Rice husk & $86 \mathrm{~kg}$ of treated rubber latex per hour & 9.8 & 3.7 \\
\hline \multirow[t]{2}{*}{ AC Generator $3 \mathrm{kWe}$} & Daikin $16 \mathrm{hp}$ & Rice husk & 300 to 500 watts & 12.0 & 2.7 \\
\hline & Daikin $16 \mathrm{hp}$ & Rice husk & 300 to 500 watts & 18.7 & 2.3 \\
\hline \multirow[t]{2}{*}{ AC Generator $3 \mathrm{kWe}$} & Robin $22 \mathrm{hp}$ & Rice husk & 450 to 710 watts & 8.3 & 4.1 \\
\hline & Robin $22 \mathrm{hp}$ & Rice husk & 450 to 710 watts & 8.5 & 4.0 \\
\hline $\begin{array}{l}\text { DC Alternator } 12 \text { volt, } \\
\qquad 60 \mathrm{amp}\end{array}$ & Daikin $16 \mathrm{hp}$ & Rice husk & $\begin{array}{l}35 \text { Amp in charging } 12 \text { volt, } \\
100 \text { AH gel type battery }\end{array}$ & 11.2 & 1.5 \\
\hline
\end{tabular}

to produce chipped ipil-ipil at a rate of $16.9 \mathrm{~kg}$ per hour with rice husk consumption of $11.5 \mathrm{~kg}$ per hour for a running period of 2.5 hours. Powering a rubber creeping mill to produce rubber blankets showed that the gasifier can drive the machine using 16-hp Yamamoto engine at a rate of $86 \mathrm{~kg}$ of treated rubber latex per hour. The gasifier consumed $9.8 \mathrm{~kg}$ of rice husk per hour for 3.7 hours of operation.

For micro electrical power generation, a 3-kWe AC generator with 16-hp Daikin engine can generate 300- to 500-watts electricity with rice husk consumption of $12.0 \mathrm{~kg}$ per hour in the first run for 2.7 hours operation and $18.7 \mathrm{~kg}$ per hour in the second run for 2.3 hours operation. Using a two-cylinder 22-hp Robin engine, the 3-kWe AC generator can generator 450- to 710 -watts power with rice husk consumption of $8.3 \mathrm{~kg}$ per hour for 4.1 hours in the first run and $8.5 \mathrm{~kg}$ per hour for 4.0 hours in the second run. Using the 16 -hp Daikin engine in driving a 12 -Volt, 60 -Amp DC alternator, that is commonly used in charging car batteries, can generate 35 amperes to charge a 12 volt, 100-AH gel-type, maintenance-free car battery with rice husk consumption of $11.2 \mathrm{~kg}$ for a period of 1.5 -hour test. 
Table 6. Operating cost analysis and payback period of the gasifier. (As of April 2018).

\begin{tabular}{|c|c|c|}
\hline & Gasifier Engine & Gasoline Engine \\
\hline Investment Cost & $90,000.00$ & $25,000.00$ \\
\hline \multicolumn{3}{|l|}{ Fixed Cost (P/day) } \\
\hline Depreciation 2/ & 31.70 & 8.81 \\
\hline Interest on Investment 3/ & 8.45 & 2.35 \\
\hline Repair and Maintenance 4/ & 3.52 & 0.98 \\
\hline Insurance 5/ & 1.06 & 0.29 \\
\hline Sub-Total & 44.74 & 12.43 \\
\hline \multicolumn{3}{|l|}{ Variable Costs (P/day) } \\
\hline Rice Husk Fuel 6/ & 40.00 & - \\
\hline Gasoline 7/ & 6.75 & 324.00 \\
\hline Engine Oil 8/ & 2.67 & 2.67 \\
\hline Sub Total & 49.42 & 326.67 \\
\hline Total Costs (P/day) & 94.15 & 339.09 \\
\hline Cost per hour & 11.77 & 42.39 \\
\hline Savings per Day & \multicolumn{2}{|c|}{ P244.94 } \\
\hline Payback Period 9/ & \multicolumn{2}{|c|}{1.22 years } \\
\hline
\end{tabular}

1) Complete set; 5 years life span. 2) Straight line with $10 \%$ salvage value. 3) $24 \%$ of the investment cost. 4) $10 \%$ of the investment cost. 5) 3\% of the investment cost. 6) P1.0 per kg of rice husks @ 1 sack per hour consumption. 7) 0.9 liter per hour @ P45/liter; for gas producer-10 min gasoline start-up per day. 8) P200.00 per liter @ 1 liter per engine-oil change every 600 hours. 9) 25 days per month for 12 months per year.

\subsection{Operating Cost Analysis and Pay-Back Period}

Table 6 shows the operating cost analysis and the payback period of the gasifier. For an investment cost of P90,000.00 (USD1 = PHP50) for the gasifier including the engine, fixed cost is P44.7 per day and variable cost is P49.42 per day. Fixed cost includes depreciation, interest on investment, repair and maintenance, and insurance. Variable cost, on the other hand, includes the cost of rice husk fuel, cost of gasoline for start-up and shut off, and cost of engine oil. The total cost in operating the gasifier is P94.15 per day or P11.77 per hour. A savings of P244.94 per day can be derived from using the ARB gasifier over using purely gasoline for the engine. If the gasifier unit will be operated for 25 days per month and 12 months per year, the payback period then is 1.22 years.

\section{Conclusions and Recommendations}

The ARB gasifier was successfully developed to provide farmers a source of power for their agricultural machines. The gasifier can also drive a small AC generator and a DC alternator to produce electricity for energizing farm houses, especially those in off-grid regions. The use of rice husks as fuel offers more ad- 
vantage in the present unit because of its properties that is highly suitable for gasification. Rice straw can also be gasified; however, there is a need to further resize it to make it suitable as fuel for the gasifier.

Coupling other agricultural machines like micromills, small threshers, axial fan (that is used in a 3-ton flatbed dryer), and many others are encouraged to further explore the applicability of the gasifier.

\section{Acknowledgements}

We would like to thank PhilRice for supporting this study to develop a gasifier suitable for our farmers. The Approtech Enterprises in San Rafael, Bulacan and FJC Agro industries in Zamboanga Sibugay for providing the area and facility to tests and evaluate the machine. Above all, to the Almighty God for the wisdom and strength He gave in coming up with the appropriate gasifier design.

\section{Conflicts of Interest}

The authors declare no conflicts of interest regarding the publication of this paper.

\section{References}

[1] Amongo, R.M.C., Amongo, L.D. and Larona, M.V.L. (2011) Mechanizing Philippine Agriculture for Food Sufficiency. The UNAPCAEM and FAO Joint Roundtable Meeting on Sustainable Agricultural Mechanization in Asia, Bangkok, 8-9 December 2011, $21 \mathrm{p}$.

[2] Bingabing, R.L. (2012) Agricultural Machinery and Situation in the Philippines. Philippine Center for Postharvest Development and Mechanization. Nueva Ecija, Philippines.

[3] Belonio, A.T., Orge, R.F., Tado, C.J.M., Regalado, M.J.C., Taylan, V.T., Paras Jr., F.O., Amongo, R.M.C. and Tadeo, B.D. (2013) Renewable Energy Technologies for Rice Mechanization. ARF Annual Rice Forum 2013-Mechanization in Rice Farming: Status, Challenges, and Opportunities. Bureau of Soil and Water Management Auditorium, SRDC Bldg. Diliman, Quezon City.

[4] Beagle, E.C. (1978) Rice Husk Conversion to Energy. Food Agricultural Service Bulletin. Food Agricultural Organization of the United Nation, Rome, 155 p.

[5] Kaupp, A. (1984) Gasification of Rice Hull: Theory and Praxix. GATE/GTZ, Federal Republic of Germany, 303 p. https://doi.org/10.1007/978-3-322-96308-6

[6] Kaupp, A. and Goss, J.R. (1984) Small Scale Gas Producer Engine Systems. GATE/GTZ. Frieds. Vieweg \& Sohn Verlagsgesellshaft mbH Braunschewerig, Federal Republic of Germany, 278 p. https://doi.org/10.1007/978-3-663-06868-6

[7] Liu, Z., Xu, A. and Zhao, T. (2011) Energy from Combustion of Rice Straw: Status and Challenges to China. Energy and Power Engineering, 3, 325-331. https://doi.org/10.4236/epe.2011.33040

[8] Ramos, P.S. (2014) Effect of Age and Size of Rice Straw on Gasification Performance. MS Agricultural Engineering Thesis Manuscript, University of the Philippines at Los Banos, Laguna, $62 \mathrm{p}$.

[9] Belonio, A.T. (2012) Rice Husk Gasifier: Theory and Applications. The 25th National Rice R\&D Conference, Philippine Rice Research Institute, Science City of 
Munoz, Nueva Ecija, Philippines, 4-6 September 2012.

[10] Belonio, A.T., Ramos, J.A., Regalado, M.J.C. and Ocon, V.B. (2013) An Overview of the Downdraft Rice Husks Gasifier for Thermal and Power Applications. Journal of Technology Innovations in Renewable Energy, 2, 246-258. https://doi.org/10.6000/1929-6002.2013.02.03.6

[11] Tiangco, V.M., Jenkins, B.M., Goss, J.R. and Chancellor, W.J. (1986) Design Development of a Continuous Small-Scale Rice Hull Gas Producer. The 1986 Summer Meeting of the American Society of Agricultural Engineers, California Polytechnic State University, San Luis Obispo, California, 29 June-2 July 1986, 31 p.

[12] Creamer, K.S., Jenkins, B.M., Goss, J.R. and Chancellor, W.J. (1986) Small-Scale Rice Hull Gas Producer-Gasoline Enginer Performance. The 1986 Summer Meeting of the American Society of Agricultural Engineers, California Polytechnic State University, San Luis Obispo, California, 29 June-2 July 1986, 30 p.

[13] Juliano, A.S., Ramos, J.A. and Molinawe, L.B. (2008) Rice Husk Power Gasifier Engine-System. The $21^{\text {st }}$ National Rice $R \& D$ Conference, PhilRice, Science City of Munoz, Nueva Ecija, Philippines, 11-13 March 2008.

[14] Hoki, M., Monobe, H., Umezawa, Y., Tadeo, B.D., Layaoen, H.Z., Cordero, J.C. and Orpilla, D.L. (2006) Rice Husk Gasification, Carbonization and Power Generation. International Agricultural Engineering Journal, 15, 169-172.

[15] Belonio, A.T., Belonio, D.A.H. and Larano, L. (2010) A Continuous-Flow Rice Husk Gasifier for Thermal Applications. The $10^{\text {th }}$ PCIERD Regional S\&T Fora and Competition, FNRI Training Room, DOST Compound, Bicutan, Taguig, Metro Manila, Philippines, $18 \mathrm{p}$.

http://www.bioenergylists.org/files/Continuous-Flow_Rice_Husk_Gasifier-Belonio2010_0.pdf

[16] Belonio, A.T., Sicat, E.V. and Cuaresma, F.D. (2011) Design and Development of a Moving-Bed Downdraft Rice Husk Gasifier for Thermal and Power Applications. Proceedings of the ERDT 7 th Conference: Sustainability through ERDT: Towards a Carbon-Neutral Economy, Manila Hotel, Manila, 16 September 2011, 17-22. 